\title{
Investment in Human Capital and Labor Productivity in Southern Key Economic Zone An Application of Propensity Score Matching Method
}

\author{
NGUYẼ̃N KHÁNH DUY \\ Master of Arts, University of Economics HCMC \\ khanhduy@ueh.edu.vn \\ NGUYẼ̃N TH!̣ HOÀNG OANH \\ Master of Arts, University of Economics HCMC \\ NGUYẼ̃N DUY TÂM \\ Institute of Development Economics Research, UEH \\ PHẠM TIẾN THÀNH \\ Master of Arts, Vietnam-Netherlands Program, UEH \\ TRUOONG THANH VŨ
}

Master of Arts, Researcher at Development Strategy Institute, MPI

\begin{abstract}
This paper investigates the determinants of human capital investment in the form of formal training (off-the-job training) and estimates effects of this investment on productivity using Propensity Score Matching (PSM) method. We use data from a survey of small and medium enterprises (SMEs) in Vietnam (completed in 2010) with detailed information about training and several firm characteristics. Our estimates reveal that investment in human capital currently does not have the considerable contribution to the improvement in productivity of SMEs. This result does not support the universalistic perspective in strategic human resource management (SHRM) theoretical model.
\end{abstract}

Keywords: evaluation, training, matching, PSM, SMEs, Vietnam, productivity, investment in human capital 


\section{INTRODUCTION}

In recent years, good progress has been found in many industries where knowledge and well-trained workers are the key factor. The accumulation of human capital plays an important role in explaining economic performance and long-term growth (Lucas, 1988). This paper conveys the importance of training in organizations as a basis for increased productivity. Training is widely understood as communication directed at a defined population for the purpose of developing skills, modifying behavior, and increasing competence. Generally, training focuses exclusively on what needs to be known. Although in organizations there is an increasing concern that training investments are justified by improved organizational performance (Salas \& CanonBower, 2001), it is difficult to find a strong evidence of this argument in the human resource literature. More and more studies have tried to estimate the effect of training on corporate productivity, they do not always agree about this effect. Some studies, such as Dearden et al. (2006), found considerable effects of training on productivity. However, Black and Lynch (2001) did not find any impact of training on productivity in their research. The main objective of this paper is to establish effects of training on the enterprise's productivity as the first step in dealing with the tension between the need for training and the doubts about its benefit to enterprises.

Although investment in human capital plays a very important role in enhancing the corporate competitiveness in the context of international integration and aftermath of global economic crisis, local enterprises, especially SMEs, do not make an appropriate investment in human capital. According to Xuân Ngọc (2011), a survey of 437 managers and 335 enterprises showed that in 2010, the budget for training was equal to $7.13 \%$ of wage fund, which means the cost per worker was only VND389,000. This percentage in 2009 was $6.89 \%$, implying that only VND313,000 was spent on training for each worker. Lê Thị Mỹ Linh (2009) stated that the majority of company owners have not been aware of the importance of training human resources, $59 \%$ of the enterprises in HCMC do not have the written training policies. Therefore, quality of human resource is hardly satisfactory due to very low investment in human capital. GSO (2011) showed that in 2010, the proportion of unskilled workers was $80.6 \%$ in the Eastern South and $92.2 \%$ in the Mekong Delta. 
The low investment in human capital may be affected more by perception of the importance of training than by shortage of financial source in enterprises. Trần Kim Dung (2011) showed that the most powerful factors affecting training activities were vision or awareness of the leaders as well as the whole workforce of the company rather than the shortage of fund for training. According to the Government's Decree 56/2009/NĐ-CP, the State offers support for training to SMEs in South Vietnam through Southern SME Technical Assistance Center. However, in 2011, the training in enterprises did not have any improvement; there were only 15 courses held by the center for 663 trainees. Xuân Ngọc (2012) stated that in fact, the companies often "hunt" skilled workers instead of training; and many enterprises are willing to spend on training activities but worried about the labors' "jumping" to another companies after training. Moreover, most of the enterprises have not evaluated the effectiveness of training activities and claimed that it was very difficult to conduct such activities.

The research in the effects of investment in human capital on productivity is highly necessary to enterprises, especially SMEs in the Southern Key Economic Zone (SKEZ). In the government strategy, this zone is considered as "driving force" which must gain a higher growth rate than the national average. However, Nguyễn Hoàng (2011) stated that highly competent labor force in this zone satisfies only $30-40 \%$ of the demand for development in enterprises.

This paper investigates the human capital investment and productivity of SMEs in HCMC and Long An Province that can represent the whole SKEZ - the most dynamic region. HCMC represents provinces in the core region, including HCM City, Bà RịaVũng Tàu, Đồng Nai, and Bình Dương, while Long An represents provinces recently joining the SKEZ: Long An, Tiền Giang, Tây Ninh, Bình Phước. The surveyed enterprises might make some, or no, investment in human capital. This may be considered as natural experiment, a good opportunity to construct control group via propensity score matching (PSM) methods in analyzing the impact of this activity on productivity.

The paper comprises five sections. The first is this introduction, and the second describes the theoretical models that explain the relationship between training and enterprises outcomes as well as the empirical studies on investigating this relationship. The third section presents our research methodology for estimation the effect of 
training on enterprises productivity. The fourth section presents our empirical results of the effect of training. The final section comprises implications and conclusion.

\section{THEORETICAL BACKGROUND}

\section{a. Theoretical Models and Empirical Studies of Relationship between Training and Enterprises' Outcomes:}

The literature on strategic human resource management (SHRM) provides a number of models to explain how training leads to enterprises' outcomes. Wright and McMahan (1992) provided a conceptual framework that incorporates six theoretical models for the study of SHRM. According to their framework and the theoretical models, HRM practices influence HR capital pool and HR behaviors; HR behaviors then lead to enterprises' outcomes. Basing on these theories that link HRM practices to enterprises' outcomes, P.Tharenou et al. (2007) proposed a theoretical framework shown in Figure 1 that links training to enterprise outcomes.

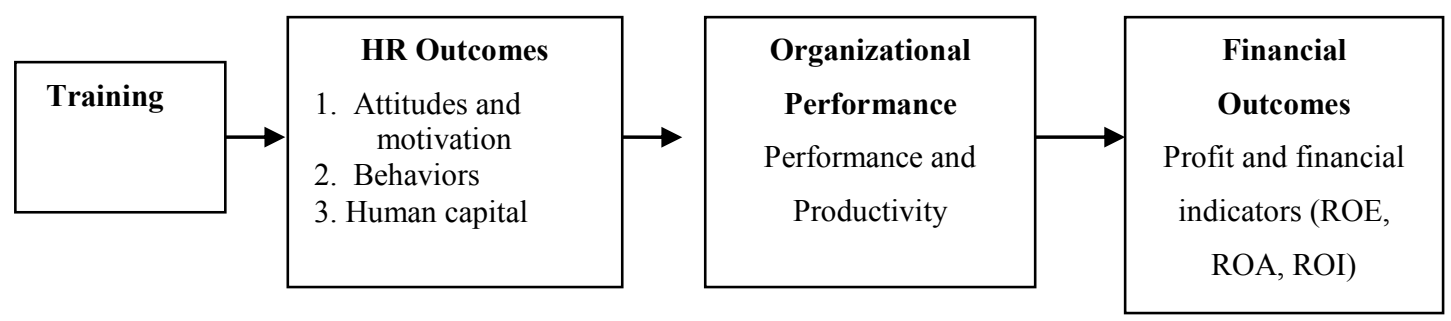

Figure 1: Theoretical Model Linking Training to Organizational outcomes.

The theoretical framework shown in Figure 1 implies a direct linear relationship between training and organizational outcomes. However, theories of SHRM (e.g., resource-based theory, behavioral theory) imply that other types of relationships also need to be considered in addition to the basic model in Figure 1. The literature on SHRM provides alternative perspectives on the relationship between HR practices and organizational outcomes that are generally referred to as the universalistic, contingency, and configurational perspectives (Delery \& Doty, 1996; Ostroff \& Bowen, 2000). These perspectives can also explain different types of relationship between training and organizational outcomes.

The most basic perspective is the universalistic one. According to this perspective, some HR practices such as formal training are work practices that are believed to be linked to organizational effectiveness for all organizations that use them (Delery \& 
Doty, 1996; Ostroff \& Bowen, 2000). The basic premise of this perspective is that the greater use of particular HR practices will result in better organizational performance, and organizations that provide more extensive training will be more effective. Basing on the universalistic perspective, training is predicted to have a positive relationship with organizational outcomes. The model shown in Figure 1 corresponds to this perspective.

A second perspective is known as the contingency perspective. The general premise of the contingency perspective is that the relationship between a specific HR practice and organizational performance is contingent on key contextual factors, and the most notable of which is organization's strategy (Delery \& Doty, 1996). Thus, organizations adopting particular strategies require certain HR practices that will be different from those required by organizations with different strategies. The contingency perspective is more complex than the universalistic perspective because it implies interactions between HR practices and organizational factors. Organizations with greater congruence between HR practices and their strategies, or other relevant contextual factors, should have superior performance (Delery \& Doty, 1996). When applied to training, the contingency perspective suggests that extensive formal training will be the most effective when used in combination with certain organizational strategies (Schuler, 1989).

A third perspective is known as the configurational perspective. This perspective suggests that there are ideal types or configurations of HR practices for HR systems that lead to superior performance (Ostroff \& Bowen, 2000). In high performance systems, HR practices need to be complementary and interdependent, working together to develop valuable, unique human capacities to increase organizational effectiveness (Barney \& Wright, 1998). When applied to training, the configurational perspective suggests that, when used in conjunction with other complementary HR practices, training will enhance organizational effectiveness better than when used independently. Thus, when enterprises invest in training, training must be consistent with other HR practices. HR practices consistent with training include careful screening of applicants for potentials and trainability, practices to decrease turnover, use of promotion from within and internal labor markets, use of performancecontingent incentive systems, defining jobs broadly, and providing opportunities for employee participation (Baron \& Kreps, 1999; Lepak \& Snell, 1999). 
In summary, the SHRM literature suggests that the nature of the relationship between training and organizational outcomes might be universalistic as suggested in Figure 1 that HR outcomes mediate the relationship between training and organizational performance. This relationship might be moderated by organizational factors such as firm strategy according to the contingency perspective or moderated by other congruent HR practices according to configurational perspective.

\section{b. Basic Framework:}

The econometric analysis in this paper follows the literature in assuming that technology at firm level can be characterized by a Cobb-Douglas production function (Dearden et al., 2006):

$$
\mathrm{Y}=\mathrm{A} \mathrm{L} \mathrm{L}^{\alpha} \mathrm{K}^{\beta}
$$

where $\mathrm{Y}, \mathrm{L}, \mathrm{K}$ are added value, labor and capital respectively; A represents technological progress, and $\alpha$ and $\beta$ denote the elasticity of added value with respect to capital and labor.

Under the assumption that trained and untrained workers have different productivities, effective labor equation can be written as:

$$
\mathrm{L}=\mathrm{N}^{\mathrm{U}}+\gamma \mathrm{N}^{\mathrm{T}}
$$

where: $\quad \mathrm{N}^{\mathrm{T}}$ and $\mathrm{N}^{\mathrm{U}}$ represent trained and untrained workers respectively, $\mathrm{L}$ is effective labor, and $\gamma$ is a parameter that characterizes trained workers' relative productivity. This parameter will be greater than 1 if trained workers are more productive than untrained workers.

Substituting equation (2) in to equation (1) we obtain:

$$
\begin{aligned}
\mathrm{Y} & =\mathrm{A}\left[\mathrm{N}^{\mathrm{U}}+\gamma \mathrm{N}^{\mathrm{T}}\right]^{\alpha} \mathrm{K}^{\beta} \\
& =\mathrm{A}\left[1+(\gamma-1) \frac{N^{T}}{N}\right]^{\alpha} \mathrm{N}^{\alpha} \mathrm{K}^{\beta}
\end{aligned}
$$

where: $\mathrm{N}$ is the total number of workers and $\frac{N^{T}}{N}$ is the ratio of trained workers to the total. Under the assumption of constant returns to scale $(\alpha+\beta=1)$ we can write the production function in intensive form and express labor productivity as follows: 


$$
\frac{Y}{N}=\mathrm{A}\left[1+(\gamma-1) \frac{N^{T}}{N}\right]^{\alpha}\left(\frac{K}{N}\right)^{\beta}
$$

Applying a $\log$ - transformation and approximating around 1, we obtain:

$$
\log \left(\frac{Y}{N}\right)=\log (\mathrm{A})+\alpha(\gamma-1) \frac{N^{T}}{N}+\beta \log \left(\frac{K}{N}\right)
$$

where: The dependent variable, labor productivity, is measured as the natural logarithm of real added value per employee from the balance sheets; $\frac{N^{T}}{N}$ is the proportion of trained workers in an industry; and $\log \left(\frac{K}{N}\right)$ is measured as the natural logarithm of the real value of tangible fixed assets from the balance sheets (plant and machinery, land and buildings, tools and equipment).

\section{c. Empirical Studies:}

- Impact of training on performance of enterprises (productivity, added value, returns...): The impact of human capital investment, especially training activities related to job, productivity, wage, or firm performance, has been studied in many countries. Ballot et al. (2001) used data from two panels of large French and Swedish firms for the same period (1987-1993), and confirmed that firm-sponsored training and R\&D are significant inputs in two countries, although to a different extent, and have high returns. Dearden et al. (2005) used panel data at firm level in England, and then indicated that one-percentage-point increase in training is associated with an increase in value added per hour of about $0.6 \%$ and an increase in hourly wages of about $0.3 \%$. Konings and Vanormelingen (2011) used the data from 1997-2006 of Belgium, and then concluded that productivity increases by $1.4 \%-1.8 \%$ in response to an increase of 10 percentage points in the share of trained workers while wage only increases by 1.0\%-1.2\%. In Vietnam, Nguyen, Ngo and Buyens (2008) surveyed 196 companies and indicated that firms which implement training activity in 2006 increased sales and productivity in both manufacturing and non-manufacturing sectors. Storey (2002) asserted that the relationship between training and firm performance works strongly enough to big firms in the US, but it is uncommon to SMEs in the UK. There is evidence that "high performance work practice" appears to be associated with better 
performance in large US companies, but argument that this relationship is less likely to be present in middle-sized companies is also supported.

Dumas \& Hanchane (2010) evaluated the impact of job-training programs, initiated by the Moroccan government and called "special training contracts", on the performance of Moroccan firms. The paper highlighted that "special training contracts" is an efficient measure of public policy. Indeed, job-training programs increase the competitiveness and performance of Moroccan firms. Additionally, it was shown that firms had different perceptions of the role of public policy. It was emphasized that training effects were higher when training was considered as part of a human resources development strategy. On the contrary, when firms considered public policies just as a financing opportunity, they did not get any returns from training.

The above researches mainly used OLS method for cross-sectional data, or GMM method for panel data. This method could not measure the real impact of training on firm performance when the selection of firms with or without training activities is not a random experiment. Very few studies applied PSM method to investigate the impact of training activities on firm performance although this is the most common technique of evaluation impact of programs, projects, policies, and discussed in the training curriculum of World Bank by Khandker et al. (2010).

Rosholm et al.(2005), with reference of evaluation methods of training activities by Heckman et al. (1999), used propensity score matching method (PSM) technique to evaluate the impact of training activities on wages - the case of the firms in Africa via constructing control group for comparison. With the combined data between firm level and personal level from Kenya and Zambia (1995), Rosholm et al. (2005) initially used Probit model to specify the determinants on the participation of employees in training activities. These included the factors related to the proprietary characteristics, job positions, membership of the union, and regional factors. In the second step, the employees were divided into treatment group and control group based on propensity score matching method, and the region of common support is specified. In the third step, evaluation impacts were developed via comparing the result of training activities and wages between the two groups. As the results, in Kenya, training activities made the wages increase by $2.3 \%$ and statistically significant at $10 \%$; while in Zambia, the impact of training activities on wages was very small and statistically insignificant. 
- Determinants of investment in human capital (training): In order to evaluate the impact of human capital investment on productivity, the firm performance, or wages; it is the most important to construct a model that reflects the determinants on human capital investment via using Logit, or Probit model. The following studies showed the determinants of the human capital investment by firms.

Forrier and Sels (2003) indicated that the investment in training was explained by number of employees, types of industry, characteristics of the internal labor market, number of contracts, number of fixed-term contracts, hours of agency work per employee, turbulence or change in the number of staff, inflow, and outflow.

Jones (2005) found that the factors affecting the probability of providing training in Australian manufacturing SMEs were introduction of major change in production technology, documented formal business plans, introduction of business improvement programs (QA, JIT), changing business structure and employment size, and innovation.

Hansson (2007) used the data from 5,824 private-sector organizations to examine determinants of training with OLS regressions. The results suggested that the most important factors in determining the provision of company training were largely related to the company management. Factors determining the provision of training including the intensity and the incidence are, with the direction of the association in brackets, whether the company analyses training needs $(+)$, whether it has a written training policy $(+)$, and the employees' educational level $(+)$. The training also depends on whether the company focuses on internal promotion (-), the degree of unionization at the firm (-) and, to some extent, on the firm's past profitability (+). The incidence of training is determined by the employees' age (-).

Guidetti and Mazzanti (2007) presented a conceptual review over the main aspects concerning the role of human capital investment and training activities within production processes, followed by empirical evidence from two local economic systems in Northern Italy, based on recent survey data. Theoretical and empirical considerations were brought together in order to provide new insights into the role of training and factors associated with training activities at firm level. This research constructed the theory of influential factors on training activities comprising the following five main groups: firm characteristics, internal labor market factors, workforce features, techno-organization innovation, and performance. Moreover, this research suggested many measurement indicators for those notions. 
The paper of Castrillón and Cantorna (2005) found that managerial decision to develop training is determined by a factor that was extraneous to the investment in new production technologies, that is to say, recruitment policies. As for the existence of a specific training budget, implementation of the advanced manufacturing technologies does not appear to determine a company's decision to allocate specific budget items to personnel-training programs. It is concluded that training policies of organizations are strongly influenced by external factors.

\section{RESEARCH METHODOLOGY}

\section{a. Main Research Questions:}

This research could help policy-planning agencies understand determinants of corporate investment in human capital thence develop policies to support enterprises and encourage them to carry out the training activities effectively. It investigates the impact of training activities on the productivity of enterprises and then enables SMEs to trust in the training activities and pay more attention to strategies for developing the human resources efficiently.

In particular, this research aims to reach the two following objectives:

(i) Specify the factors that affect investment in human capital (training) in SMEs in SKEZ.

(ii) Measure the impact of human capital investment on labor productivity.

In order to achieve these two objectives, the research will focus on answering the following questions:

(1) Do the factors related to firm characteristics (scales, type of industry, etc...), state of technology, labor characteristics, and innovation have any impacts on the human capital investment by SMEs?

(2) How is the impact of human capital investment on the productivity of SMEs?

\section{b. Main Hypotheses and Research Model:}

Based on the literature review and empirical studies, the model of determinants of human capital investment in SMEs in SKEZ may include explanatory variables with the expected sign as shown in Table 1.

Some main hypotheses are as follows:

$\mathrm{H}_{1}$. The firm scale has positive impacts on the human capital investment by SMEs. 
$\mathrm{H}_{2}$. The firms with higher proportion of managers and employees with university or college degrees will have larger human capital investments.

$\mathrm{H}_{3}$. The firms with business plans will have higher human capital investment than the firms without business plans.

$\mathrm{H}_{4}$. The firms who are members of the trade associations will invest in human capital more than the others.

Table 1: The Expected Variables in Logit/ Probit Model

\begin{tabular}{|c|c|c|c|c|}
\hline & & Note & $\begin{array}{l}\text { Expected } \\
\text { sign }\end{array}$ & $\begin{array}{l}\text { Calculated } \\
\text { from } \\
\text { questions }\end{array}$ \\
\hline \multirow[t]{3}{*}{ I } & Dependent variable & & & \\
\hline & Investment in human capital (training) & 1: Yes & & $\mathrm{Aq} 76, \mathrm{Aq} 77$ \\
\hline & & $0:$ No & & Aq90ae \\
\hline II & Independent variables & & & \\
\hline \multirow[t]{2}{*}{1} & $\ln ($ size $)$ & Continuous & + & \\
\hline & Total assets & & & $\mathrm{Aq} 93 \mathrm{c}$ \\
\hline 2 & Age of firm & Continuous & + & Aq6a \\
\hline 3 & Industrial park/zone (IZ) & Dummy & + & Aq5 \\
\hline 4 & Form of ownership/legal status & Dummies & $?$ & Aq12a \\
\hline 5 & $\begin{array}{l}\text { Percentage of managers, professionals, } \\
\text { office workers }(\%)\end{array}$ & Continuous & $?$ & $\mathrm{Aq} 74$ \\
\hline 6 & Turnover & Continuous & - & $\mathrm{Aq} 75$ \\
\hline 7 & Business plan & Dummy & + & Aq141 \\
\hline \multirow[t]{2}{*}{8} & Constraints to growth & Dummy & + & Aq133 \\
\hline & $\begin{array}{l}\text { Does the firm face any major constraints } \\
\text { to growth? }\end{array}$ & & & \\
\hline 9 & $\begin{array}{l}\text { Negatively affected by the global } \\
\text { economic crisis }\end{array}$ & Dummy & - & Aq133b \\
\hline 10 & Member of one or more trade associations & Dummy & + & Aq125 \\
\hline 11 & Network & Dummy & $?$ & Aq123 \\
\hline
\end{tabular}


Percentage of workers who are trade unionists

13 The long-term attachment

Dummies

Buying social, insurance, health insurance

for employees

14 Labor market

Dummies

How does the enterprise hire workers?

Aq79

Is there any difficulties in recruiting Aq80 workers with the required/appropriate skill level

15 Percentage of short-term contracts (\%)

Continuous

?

Aq73e

16 Research and development (R\&D)

Continuous

Aq90ad

17 Percentage of modern technology (\%)

Continuous

Aq29

18 Innovation

Number of personal computers

Dummies

Aq34a

Sell products via e-trading

(And/or)

Aq34b

Purchase services from outside the Continuous Aq65 enterprise

Aq78

Automatic job rotation system

Aq56

Days of inventory

Aq90af

The firm has made major improvements in Aq129 existing products or changed specification The firm has introduced new production processes/new technology since August

Environmental standards certificate

19 The firm has been involved in training

Dummy

Aq135 courses supported by the national or international organizations

20 Government assistance

Dummy 
$\mathrm{H}_{5}$. The firms with modern technology will have greater investment in human capital than the firms without modern technology.

After estimating the research model in order to test five main hypotheses above, this study will analyze the impact of the human capital investment on productivity and indicators reflecting the firm performance via using PSM techniques in order to test Hypothesis 6.

$\mathrm{H}_{6}$. Human capital investment results in increases in the productivity of SMEs.

This hypothesis is worth being tested because many big companies have recently paid attention to training activities (Xuân Ngọc, 2012), and Trần Kim Dung (2011) stated that in HCMC the training activities in such enterprises are still very wasteful and inefficient. Nguyễn Tùng (2012) find that there is a positive relationship between training activities and growth rate of profit (correlation=0.54). In Vietnam, Nguyen, Ngo and Buyens (2008) surveyed 196 companies and indicated that firms which implement training activity in 2006 have increased sales and productivity in both manufacturing and non-manufacturing sectors. If the hypothesis $\mathrm{H}_{6}$ is accepted via using a significant method, it will enable the enterprises to trust in the training activities as well as enable the government to promote the training support for SMEs.

\section{c. Methodology:}

This research uses qualitative methods to answer the research questions. Question 1 would be solved by Probit technique. Question 2 will be solved by PSM method. PSM constructs a statistical comparison group that is based on a model of the probability of participating in the treatment by using observed characteristics. Participants are then matched, on the basis of this probability or propensity score, to non-participants. The average treatment effect of the program is then calculated as the means difference in outcomes across these two groups (Khandker et al., 2010).

This research does not employ traditional methods, such as multiple regressions, to investigate the impact of investment in human capital on productivity because such methods are only reasonable with respect to randomized experiments. The greatest difficulty of impact evaluation is to identify the outcome without the program; in 
particular, the difficulty in this research is to identify the potential outcome if the enterprises do not invest in human capital. Of course, we cannot find an enterprise that both invest and does not invest in human capital at the same time. A lot of techniques for impact evaluation (such as PSM, DID, Match DID, etc.) help us to construct counterfactual outcomes in order to compare with the enterprises which invest in human capital, and then the problem of causal effect of the programs/ associated policies on the outcome is settled (Khandker et al., 2010).

\section{d. Data:}

This research uses the secondary surveyed data of SMEs in Vietnam in 2009 collected by CIEM (completed in 2010); and the data from HCMC and Long An in order to estimate the model. Due to the simplicity as well as the ability to evaluate the impact of investment in human capital on productivity or results of training activities, this research applies PSM method using SMEs data to estimate the model.

The surveyed data of SMEs are conducted by the Central Institute for Economic Management (CIEM) under Ministry of Planning and Investment (MPI), Institute of Labor Science and Social Affairs (ILSSA) under Ministry of Labor, Invalids and Social Affairs (MOLISA); Department of Economics, Copenhagen University; and Embassy of Demark in Vietnam. The year of 2009 is included in the $6^{\text {th }}$ survey (conducted once every 2 years).

The surveyed data of SMEs in 2007 and 2009 include individual businesses (or household businesses) that do not meet the requirements in Vietnam's Companies Law and the businesses that officially register according to this law. The surveyed samples do not include the joint-venture businesses. In the survey, CIEM (2010) applies World Bank's definition of SMEs that classifies enterprises as follows: Ultra-Small Enterprises: 1-9 laborers; Small Enterprises: 10-49 laborers; Medium Enterprises: 50299 laborers; Big Enterprises: more than 300 laborers. This definition is widely accepted by the Government of Vietnam (Refer to the Government Decree 90/2001/ND-CP on official support for development of SMEs. In addition, the definition of SMEs also relies on total capital (total asset) and is flexibly applied during the survey.

Decree 56/2009/NĐ-CP on the support for development of SMEs promulgated on June 30, 2009 prescribes that small and medium businesses that make registration in accordance with law, are divided into three levels: micro, small and 
medium scale of total capital (total capital equivalent to total assets is stated in the balance sheet of enterprises) or number of employees per year (total funding is the priority criteria), specifically as follows:

Table 2: Classification of Enterprises

\begin{tabular}{|c|c|c|c|c|c|}
\hline \multirow[b]{2}{*}{ Sector } & \multirow{2}{*}{$\begin{array}{l}\text { Ultra-Small } \\
\text { Enterprise }\end{array}$} & \multicolumn{2}{|c|}{ Small Enterprise } & \multicolumn{2}{|c|}{ Medium Enterprise } \\
\hline & & $\begin{array}{c}\text { Total } \\
\text { capital }\end{array}$ & Labor force & $\begin{array}{c}\text { Total } \\
\text { capital }\end{array}$ & Labor force \\
\hline $\begin{array}{c}\text { I. Agriculture, } \\
\text { Forestry and } \\
\text { Fishery }\end{array}$ & $\begin{array}{c}10 \text { persons } \\
\text { or fewer }\end{array}$ & $\begin{array}{l}\text { VND } 20 \\
\text { billion or } \\
\text { less }\end{array}$ & $\begin{array}{c}\text { Between over } 10 \\
\text { persons and } 200 \\
\text { persons }\end{array}$ & $\begin{array}{l}\text { Between over } \\
\text { VND } 20 \\
\text { billion and } \\
\text { VND } 100 \\
\text { billion }\end{array}$ & $\begin{array}{c}\text { Between over } 200 \\
\text { persons and } 300 \\
\text { persons }\end{array}$ \\
\hline $\begin{array}{l}\text { II. Industry and } \\
\text { Construction }\end{array}$ & $\begin{array}{c}10 \text { persons } \\
\text { or fewer }\end{array}$ & $\begin{array}{l}\text { VND } 20 \\
\text { billion or } \\
\text { less }\end{array}$ & $\begin{array}{c}\text { Between over } 10 \\
\text { persons and } 200 \\
\text { persons }\end{array}$ & $\begin{array}{l}\text { Between over } \\
\text { VND } 20 \\
\text { billion and } \\
\text { VND } 100 \\
\text { billion }\end{array}$ & $\begin{array}{c}\text { Between over } 200 \\
\text { persons and } 300 \\
\text { persons }\end{array}$ \\
\hline $\begin{array}{l}\text { III. Commerce } \\
\text { and Service }\end{array}$ & $\begin{array}{l}10 \text { persons } \\
\text { or fewer }\end{array}$ & $\begin{array}{l}\text { VND } 10 \\
\text { billion or } \\
\text { less }\end{array}$ & $\begin{array}{c}\text { Between over } 10 \\
\text { persons and } 50 \\
\text { persons }\end{array}$ & $\begin{array}{l}\text { Between over } \\
\text { VND } 10 \\
\text { billion and } \\
\text { VND } 50 \\
\text { billion }\end{array}$ & $\begin{array}{c}\text { Between over } 50 \\
\text { persons and } 100 \\
\text { persons }\end{array}$ \\
\hline
\end{tabular}

Additionally, Decree 56/2009/NĐ-CP stated that depending on the nature and objectives of each policy and support program, governing agencies can modify the above criteria to make them more appropriate.

The survey of SMEs in 2009 collects information from 2,655 SMEs in 10 cities/provinces in Vietnam. There are 634 enterprises in HCMC (23.88\%), 133 in Long An (5.01\%); therefore, the total number of enterprises in HCMC and Long An are 767 (28.89\%). These include 20 firms in industrial parks, two firms in hightech parks, and others located outside industrial and high-tech parks. The in-sample firms surveyed in HCMC and Long An were established before 2007, and 90\% of 
them were established before 2005. In 2008, there were 152 firms that invested in training activities for new employees or current staff. This does not include on-thejob training. Only well-organized full-time training within less than six months (a year) was included here.

The data of enterprises in HCMC and Long An consists of 428 households (55.8\%), 96 private/sole proprietorship (12.52\%), 13 collective/cooperatives (1.69\%), 221 limited liability companies (28.81\%) and nine private joint-stock companies (1.17\%).

Turnover, added values, net profit, productivity (profit/labor) of firms based on 1994 comparative price and number of employees are shown in Table 3.

Table 3: Turnover, Added Values, Net Profit and Labor Force in 2009

\begin{tabular}{lccccc}
\hline \multicolumn{1}{c}{ Variable } & $\begin{array}{c}\text { Number of } \\
\text { observations }\end{array}$ & Mean & Std. Dev. & Min & Max \\
\hline Total real turnover (VND mil.) & 740 & $2,101.86$ & $6,549.50$ & 12.96 & $84,279.09$ \\
Total real values added (VND mil.) & 740 & 516.12 & $1,516.47$ & 1.72 & $22,044.23$ \\
Net Profit (VND mil.) & 740 & 350.10 & $1,320.52$ & -100.10 & $21,947.93$ \\
Productivity & & & & & \\
(VND mil./person/year) & 740 & 19.40 & 34.97 & 0.43 & 847.85 \\
Labor force (person) & 767 & 20.53 & 39.29 & 1.00 & 650.00 \\
\hline
\end{tabular}

Note: Calculated from CIEM data (2010)

\section{RESULTS}

\section{a. Descriptive Statistics in Labor Productivity:}

Table 4 shows the average labor productivity is VND28.46 million per worker in enterprises with training program but it is only VND18.14 million in enterprises without training. The labor productivity herein is measured by the division of the added value expressed in 1994 base price and the size of labor force. The two-sample t-test gives the sufficient evidence of the difference in labor productivity at significant level of $10 \%$. However, there are still many other determinants of labor productivity. Moreover, this estimate may be inaccurate and biased because division of enterprises into training and not training groups is not random. 
Table 4: Two-Sample t -Test with Unequal Variances

\begin{tabular}{lcccccc}
\hline \multicolumn{1}{c}{ Group } & Obs & Mean & Std. Err. & Std. Dev. & [95\% Conf. & Interval] \\
\hline Not Training & 526 & 18.14 & 0.74 & 16.98 & 16.69 & 19.60 \\
Training & 148 & 28.46 & 5.80 & 70.50 & 17.00 & 39.91 \\
combined & 674 & 20.41 & 1.40 & 36.45 & 17.65 & 23.16 \\
\hline difference & & -10.32 & 5.84 & & -21.86 & 1.23 \\
(t) & $(-1.76)$ & & & & \\
(P-value) & & $(0.08)$ & & & & \\
\hline
\end{tabular}

Note: Calculated from CIEM data (2010)

This paper applies PSM method to find a counterfactual case that allows comparison between enterprises with and without training programs, which could evaluate the effects of training on productivity. This method consists of three main stages: (1) Estimating a model of Program Participation, (2) Defining the region of common support and balancing tests, (3) Matching participants to non-participants (Khandker et. al., 2010). The results in the next sections will be analyzed according to these three stages.

\section{b. Probit Model on the Determinants on Investment in Human Capital:}

Firstly, estimates of the Probit model on the determinants of investment in human capital (training) are showed in Table 5. The model indicates that the firm size does not account for the probability of investment in human capital. The firm type significantly affects the probability of investment in human capital (e.g. private household businesses have the lowest probability of human capital investment). The proportion of office staff (including managers, staff with university/college degree, and other whitecollar employees) has a negative relationship with the probability of training; $1 \%$ increase in this proportion will lead to a decrease of 0.25 in the probability of training. The proportion of causal labors has a positive effect on the likelihood of the investment in training; the probability of training increases by 0.26 when this proportion increases by $1 \%$. Therefore, factors related to the characteristics of labor force do have significant effects on probability of investment in human capital by firms.

In addition, there is no evidence of the relationship between turnover (the ratio of entering labors minus leaving labors to total labor) and probability of training; 
however, firms with policy on downsizing due to restructuring of workforce have higher probability of training. Firms with business plans are also more likely to make investment in training. This is evident by the statistical significance of the variables restructuring and businessplan. With $1 \%$ increase in the proportion of causal labor, the probability of investment in training rises by 0.061 .

The Probit model shows that there is no statistically significant relationship between the support of international sponsors and the probability of training; however, there is a remarkable difference in training probability between firms with the government support and those without government support. With the support from the government, the probability of investment in training increases by 0.16 .

The survey was carried out in the recession period, but the fact that firms were under the negative impacts of this crisis, or encountered constraints to growth, has no effect on the probability of investment in training. The result shows that the variables crisis and constraints are statistically insignificant.

Firms which are members of a trade association have higher probability of training by 0.21 than those who are non-member of any association (The association variable is statistically significant). In addition, there is no evidence of relationship between the percentage of employees participating in trade union and the probability of training.

Firms with higher proportion of short-term labor contracts (under 3 months) have greater probability of investment in training. The result shows that shorttermcon variable is positively significant.

There has been no evidence of relationship between $R \& D$ and the probability of training; however, the technology applied by firms has impact on the training probability. Firms with modern technology are more likely to invest in training.

The methods of recruiting workers (via advertisement in newspapers, centers of labor service, recommendation from local authorities, or relationships) have no effect on the training probability. However, when firms have difficulties in recruiting suitable workers, the probability of training increase (The diffrecruiting variable has a positive sign and statistical significance).

Firms with long-term policies such as paying medical and social insurance for their employees have higher probability of training than those without these policies. 
The innovation of a firm is measured by several variables. Among these variables, etrading (Selling products via e-trading), inventory (Days of inventory), improveproducts (Firms with major improvements in existing products or changed specification) are statistically significant with negative signs. The negative sign implies that greater innovation results in less training.

The manufacturing sector and service sector have influence on the probability of training. HCMC-based firms have a higher probability of training than those in Long An.

The Probit model in Table 5 has no multicollinearity $(\mathrm{VIF}<5)$ and has good accuracy level by the Count $\mathrm{R}^{2}=85.9 \%$

Table 5 : Probit Model

\begin{tabular}{lccccccc}
\hline & Coef. & Std. Err. & $\mathbf{z}$ & $\mathbf{P}>|\mathbf{z}|$ & $\mathbf{V I F}$ & Marginal Effects & Mean \\
\hline lnassets & 0.009 & 0.066 & 0.140 & 0.886 & 1.810 & 0.002 & 6.649 \\
firmage & 0.01 & 0.009 & 1.130 & 0.259 & 1.260 & 0.002 & 11.907 \\
industrialpark & -0.617 & 0.450 & -1.370 & 0.170 & 1.160 & -0.090 & 0.029 \\
\hline private & $0.458^{*}$ & 0.250 & 1.830 & 0.067 & 1.640 & 0.114 & 0.134 \\
cooperative & 0.518 & 0.503 & 1.030 & 0.303 & 1.200 & 0.139 & 0.017 \\
Limited_Jointstock & 0.018 & 0.225 & 0.080 & 0.937 & 2.440 & 0.004 & 0.325 \\
\hline officeworkers & $-1.185^{*}$ & 0.611 & -1.940 & 0.052 & 1.380 & -0.247 & 0.248 \\
casuallabor & $1.231 * * *$ & 0.466 & 2.640 & 0.008 & 1.170 & 0.257 & 0.061 \\
turnover & -0.001 & 0.004 & -0.220 & 0.830 & 1.130 & 0.000 & -3.189 \\
restructuring & $1.214 * * *$ & 0.226 & 5.360 & 0.000 & 1.250 & 0.380 & 0.093 \\
businessplan & $0.685 *$ & 0.390 & 1.760 & 0.079 & 1.120 & 0.099 & 0.938 \\
crisis & 0.057 & 0.188 & 0.300 & 0.761 & 1.190 & 0.012 & 0.748 \\
constraints & -0.025 & 0.243 & -0.100 & 0.919 & 1.220 & -0.005 & 0.895 \\
govassistance & $0.737 * * *$ & 0.162 & 4.540 & 0.000 & 1.320 & 0.183 & 0.279 \\
foreigndonors & -0.179 & 0.379 & -0.470 & 0.637 & 1.220 & -0.034 & 0.040 \\
association & $0.734 * *$ & 0.290 & 2.530 & 0.011 & 1.310 & 0.209 & 0.055
\end{tabular}




\begin{tabular}{|c|c|c|c|c|c|c|c|}
\hline network & $-0.666^{* * *}$ & 0.174 & -3.820 & 0.000 & 1.160 & -0.170 & 0.797 \\
\hline union & 0.304 & 0.261 & 1.160 & 0.244 & 1.760 & 0.064 & 0.127 \\
\hline shorttermcon & $0.008 * * *$ & 0.003 & 2.620 & 0.009 & 1.490 & 0.002 & 21.256 \\
\hline $\mathrm{R} \& \mathrm{D}$ & 3.551 & 6.077 & 0.580 & 0.559 & 1.120 & 0.742 & 0.001 \\
\hline moderntechnology & $0.442 *$ & 0.262 & 1.690 & 0.092 & 1.160 & 0.092 & 0.163 \\
\hline newspaperad & 0.086 & 0.272 & 0.320 & 0.751 & 1.180 & 0.019 & 0.066 \\
\hline localauthorities & -0.206 & 0.494 & -0.420 & 0.677 & 1.080 & -0.038 & 0.027 \\
\hline emcenter & 0.005 & 0.240 & 0.020 & 0.983 & 1.260 & 0.001 & 0.096 \\
\hline diffrecruiting & $0.944 * * *$ & 0.163 & 5.790 & 0.000 & 1.260 & 0.253 & 0.232 \\
\hline healthsocialins & $0.463 * *$ & 0.212 & 2.190 & 0.029 & 2.300 & 0.105 & 0.340 \\
\hline etrading & $-0.833 * *$ & 0.368 & -2.270 & 0.023 & 1.130 & -0.109 & 0.046 \\
\hline computer & 0.017 & 0.016 & 1.020 & 0.306 & 1.650 & 0.003 & 2.107 \\
\hline servoutside & 0.21 & 0.183 & 1.150 & 0.249 & 1.370 & 0.042 & 0.678 \\
\hline inventory & $0.096 * *$ & 0.047 & 2.060 & 0.039 & 1.220 & 0.020 & 3.233 \\
\hline improveproducts & $-0.35^{* *}$ & 0.151 & -2.320 & 0.021 & 1.200 & -0.073 & 0.498 \\
\hline envstandard & -0.053 & 0.185 & -0.290 & 0.775 & 1.290 & -0.011 & 0.191 \\
\hline industryl & 0.484 & 0.374 & 1.290 & 0.196 & 3.850 & 0.116 & 0.232 \\
\hline industry 2 & $0.731 * *$ & 0.355 & 2.060 & 0.040 & 2.990 & 0.194 & 0.172 \\
\hline industry3 & 0.286 & 0.419 & 0.680 & 0.495 & 1.910 & 0.068 & 0.070 \\
\hline industry4 & 0.226 & 0.352 & 0.640 & 0.522 & 3.650 & 0.050 & 0.256 \\
\hline industry 5 & $0.839 * *$ & 0.368 & 2.280 & 0.023 & 2.330 & 0.239 & 0.107 \\
\hline industry 7 & $0.806^{*}$ & 0.480 & 1.680 & 0.093 & 1.490 & 0.238 & 0.034 \\
\hline industry8 & $0.766^{*}$ & 0.403 & 1.900 & 0.057 & 1.730 & 0.221 & 0.053 \\
\hline$H C M C$ & $0.53 *$ & 0.282 & 1.880 & 0.061 & 1.950 & 0.089 & 0.854 \\
\hline cons & -3.491 & 0.81 & -4.33 & 0.00 & & & \\
\hline
\end{tabular}


Pseudo R2 $\quad 0.379$

Count R square $\quad 0.859$

n

656.000

Notes: Dependent variable: Train $(1=$ Yes, $0=$ No); italic variables are dummies;

$* \mathrm{P}<0.1, * * \mathrm{P}<0.05, * * * \mathrm{P}<0.01$

Calculated from CIEM data (2010)

Secondly, the region of common support is $[.00513151 ; .98578018]$ and the balancing property is satisfied.

\section{c. Impact Evaluation of the Human Capital (training) Investment on Productivity:}

PSM method uses a variety of techniques to compare results of treatment and control group. Each technique has its own advantage and limitation. We calculate the impact by using different techniques to check the consistency.

Table 6: The Treatment Effect on the treated (TOT)

\begin{tabular}{lccccc}
\hline \multicolumn{1}{c}{ Method } & Treatment & Control & ATT & SE & t \\
\hline Nearest Neighbor Matching & 145 & 73 & 1.494 & 8.433 & 0.177 \\
Stratification & 145 & 511 & 7.883 & 6.156 & 1.281 \\
Radius Matching & 46 & 95 & 18.114 & 18.341 & 0.988 \\
Kernel Matching method with & 145 & 463 & 6.657 & 6.583 & 1.011 \\
Bootstrapped standard errors & & & & & \\
\hline
\end{tabular}

Note: Calculated from CIEM data (2010)

From Table 6, with the application of four different techniques of PSM, the investment in human capital (training) by SMEs in SKEZ is found to increase the productivity, but the increasing rate is insignificant (the absolute value of $t$ statistics is too small even when being considered at a significant level of $10 \%$ ). Based on Khandker et al. (2010), the result using Kernel Matching technique with Bootstrapped standard errors is better than those from other techniques. The result using this technique shows that the investment in human capital of the SMEs in HCMC and Long 
An leads to an increase in productivity by VND6.6 million per capita per year, but this number is not statistically significant $(\mathrm{t}=1.011)$

Table 7 shows the results of the Treatment effect on the treated (TOT) with calculation of logarithm value of productivity.

Table 7: The Treatment Effect on the Treated (TOT) with In(productivity)

\begin{tabular}{lccccc}
\hline \multicolumn{1}{c}{ Method } & Treatment & Control & ATT & SE & t \\
\hline Nearest Neighbor Matching & 145 & 73 & -0.086 & 0.159 & -0.54 \\
Stratification & 145 & 511 & 0.091 & 0.089 & 1.016 \\
Radius Matching & 46 & 95 & 0.219 & 0.151 & 1.452 \\
Kernel Matching method & 145 & 463 & 0.051 & 0.093 & 0.542 \\
Bootstrapped standard errors & & & & & \\
\hline
\end{tabular}

Note: Calculated from CIEM data (2010)

The results based on the calculation of $\ln$ (productivity) indicate that the impact of training activity on productivity is still insignificant (even when being considered at significant level of 10\%). Kernel matching technique with Bootstrapped standard errors shows that the investment in human capital results in an increase in productivity by $5.1 \%$; however, this number is not statistically significant.

\section{IMPLICATIONS AND CONCLUSION}

By applying PSM method, this paper indicates that the investment in human capital (training) by SMEs in SKEZ does not significantly increase their productivity. This result is consistent with findings by Storey (2002) for the case of SMEs in UK, and by Black and Lynch (2001); however, this result is inconsistent with the research by Nguyen, Ngo and Buyens (2008) for the case of firms in Vietnam. The insignificant effects of training on productivity in this paper do not support the universalistic perspective in SHRM theoretical model. The effectiveness of training activity in SMEs herein needs to be re-considered together with the organizational strategy in contingency perspective and other HR practices in configurational perspective.

The effectiveness of training activities regarding the improvement in productivity is insignificant. It may come from the fact that the SMEs do not pay much attention to training activities as well as their effectiveness; only few firms have obvious training 
plans, and most of the firms have not established an appropriate connection between these plans with human resource management (recruitment, training, wage, motivation, work allocation, etc.,) as well as the administration activities of the firms. Some firms do not consider training activities as an opportunity to improve firm's effectiveness and productivity, but as a chance to get disbursement, enjoy some free tours, and obtain personal benefits.

The group of qualified organizations, experts, instructors, and trainers that meet requirements of the firms will also make a remarkable contribution to the increase in the effectiveness of training activities. Training program and training contents closely connected with each specific job or situation of each firm will enable their workers to apply new knowledge quickly. In addition to on-the-job or off-the-job training activities held by the firms, the firms can coordinate with training organizations/ institutions to establish a specific and appropriate training program rather than an unspecific one.

The support from the government in verification of and improvement in quality of training courses supplied by educational organizations/ institutions, colleges, or universities will establish an efficient labor market, and a high-quality short-term training services, from which the firms can easily recruit and train labor force with high skill, good knowledge and appropriate attitude, thereby saving training cost and increasing labor productivity.

This study also states that the support from government or trade associations plays a significant role in the investment in human capital of a firm. However, it is essential that the quality of training programs for improving productivity should be paid more attention to.

Nowadays, the trade union is not the factor that affects the probability of investment in human capital. This may be due to the ineffectiveness of trade unions, or because trade unions are paying too more attention to the cultural or sport events than to the improvement in labor skills.

The results also show that firms with modern technology are more likely to invest in human capital, which enables workers to master new technology and thence take advantage of new equipment to increase productivity.

Additionally, firms with clear business plans also have higher investment in human capital. Therefore, the government, non-governmental organizations, or training 
institutions/ centers should support the SMEs with ability to devise and manage business plans. Thence, these firms will have clear strategies, plans; and in the long term, they will pay more attention to human resource and training activities as well.

Endnote: We would like to thank for the support to our research from Mekong Economic Research Network Project

\section{References}

Central Institute for Economic Management - CIEM (2010a). The Survey data of SMEs in 2009

Central Institute for Economic Management - CIEM (2010b), Đặc điểm môi truòng kinh doanh ở Việt Nam: Kết quả điều tra doanh nghiệp nhỏ và vìa năm 2009 (Characteristics of the Vietnamese business climate: Evidence from a SME survey in 2009), Tài Chánh Publisher

Ballot, G., F. Fathi \& E. Taymaz (2001), “Firms' Human Capital, R\&D and Performance: A Study on French and Swedish Firm”, Labour Economics, 8, pp. 443-462.

Barney, J.B, \& P.M. Wright (1998), “On Becoming a Strategic Partner", Human Resource Management, 37, pp. 31-46.

Baron, I.N. \& D.M. Kreps (1999), “Consistent Human Resource Practices”, California Management, 41, pp. 29-53.

Black, S.E. \& L.M. Lynch (2001), "How to Compete: The Impact of Workplace Practices and Information Technology on Productivity", The Review of Economies and Statistics, 83(3), pp. 434-445.

Castrillón, I.D. \& A.I.S. Cantorna (2005), "The Effect of the Implementation of Advanced Manufacturing Technologies on Training in the Manufacturing Sector", Journal of European Industrial Training, 29 (4), pp. 268-280.

Conti, G. (2007), “Training, Productivity and Wages in Italy”, Labour Econometrics, 12, pp. 557576.

Dearden, L., H. Reed \& J.V. Reenen (2006), "The Impact of Training on Productivity and Wages: Evidence from British Panel Data", Oxford Bulletin of Economics and Statistics 68(4), pp. 397 421.

Dumas, A. \& S. Hanchane (2010), "How Does Job-Training Increase Firm Performance? The Case of Morocco", International Journal of Manpower, 31(5), pp. 585-602.

Delery, J.E. \& D.H. Doty, (1996), "Modes of Theorizing in Strategic Human Resource Management", Academy of Management Journal, 39, pp. 802-835.

Forrier, A. \& L. Sels (2003), "Flexibility, Turnover and Training", International Journal of Manpower, 24 (2), pp. 148-168. 
Gertler, P.J. et al. (2011), Impact Evaluation in Practice, The Worldbank

GSO (2011), "Báo cáo điều tra lao động - việc làm Việt Nam 2010” (Report on Labor Force Survey 2010)

Guidetti, G. \& M. Mazzanti (2007), "Firm-Level Training in Local Economic Systems Complementarities in Production and Firm Innovation Strategies", The journal of SocioEconomics, 36, pp. 875-894.

Hansson, B. (2007), "Company-Based Determinants of Training and the Impact of Training on Company Performance: Results from an International HRM Survey”, Personnel Reviews, 36 (2), 311-331

Jones, J.T. (2005), "The Determinants of Training in Australian Manufacturing SMEs", Education+Training, 47(8), pp. 605-615.

Khandker, S.R., G.B. Koolwal \& H.A. Samad (2010), Handbook on Impact Evaluation Quantitative Methods and Practices. The World Bank.

Konings, J. \& S. Vanormelingen (2011), “The Impact of Training on Productivity and Wages: Firm Level Evidence", working paper, IESE Business School and HU Brussels, retrieved from: http://ftp.iza.org/dp4731.pdf

Lepak, D.P. \& S.A Snell (1999), “The Human Resource Architecture”, Academy of Management Review, 24, pp. 31-48.

Lê Thị Mỹ Linh (2009), "Phát triển nguồn nhân lực trong doanh nghiệp nhỏ và vừa ở Việt Nam trong quá trình hội nhập kinh tế" (Human resource development in small and medium enterprises in Vietnam in the process of economic integration), unpublished doctoral dissertation, National University of Economics.

Lucas, R.E. (1988), “On the Mechanics of Economic Development", Journal of Monetary Economics, 22(1), pp. 3-42.

Nguyễn Hoàng (2011), "Để Vùng kinh tế trọng điểm phía nam phát triển nhanh và bền vững” (For a fast and sustainable development for the Southern Key Economic Zone), Kinh tế Việt Nam, available at http://www.ven.vn/\%C3\%B0e-vung-kinh-te-trong-diem-phia-nam-phat-trien-nhanhben-vung t77c440n19196tn.aspx on July 17, 2012

Nguyen N.T, Ngo V.T. \& D. Buyens (2008), “The Impact of Training on Firm Performance: Case of Vietnam", Working paper, the $7^{\text {th }}$ International Conference of the Academy of Human Resource Development, Bangkok, Thailand, Nov. 3-6 2008, retrieved from: http://www.feb.ugent.be/nl/Ondz/wp/Papers/wp_08_538.pdf

Nguyễn Tùng (2012). Thực tiễn quản trị nhân sự và hiệu quả hoạt động của các doanh nghiệp nhỏ và vừa tại Việt Nam (HR practices and performance of small and medium enterprises in Vietnam), Working paper, retrieve from http://www.prompt.vn/anh/sharedocument/1003135115Quan\%20tri\%20nhan\%20su\%20tai\%20c ac\%20SME\%20Viet\%20Nam.pdf on June 26, 2012 
Ostroff, C. \& D.E. Bowen (2000), „Moving HR to a Higher Level: HR Practices and Organizational Effectiveness" in K.J.Klein, \& S.W. Kozlowski (eds.), Multilevel Theory, Research, and Methods in Organizations (pp.211-266) San Francisco, CA: Jossey-Bass.

Rosholm, M., H.S. Nielsen \& A. Dabalen (2005), "Evaluation of Training in African Enterprises", Journal of Development Economics, 84, pp. 310-329.

Salas, E., \& J.A. Canon-Bowers (2011), "The Science of Training: A Decade of Progress", Annual Review of Psychology, 52, pp. 471-499.

Schuler, R.S. (1989), "Strategic Human Resource Management and Industrial Relations", Human Relations, 42, pp. 157 -184.

Storey, D.J. (2002), "Education, Training and Development Policies and Practices in Medium-Size Companies in UK: Do They Really Influence Firm Performance?", Omega - The International Journal of Management Science, 30, pp. 249-264.

Tharenou, P., A.M. Saks \& C. Moore (2007), “A Review and Critique of Research on Training and Organizational-Level Outcomes”, Human Resource Management Review, 17, pp. 251-273.

Wright, P.M. \& G.C. McMahan (1992), Theoretical Perspectives for Strategic Human Resource Management”, Journal of Management, 18, pp. 295-320.

Xuân Ngọc (2011), "Doanh nghiệp Việt Nam đầu tư thấp cho đào tạo" (Vietnam enterprises invest less in training), retrieve from http://vnexpress.net/gl/kinh-doanh/2011/11/doanh-nghiep-vietdau-tu-thap-cho-dao-tao-nhan-luc/ on June 25, 2012

Xuân Ngọc (2012), "Doanh nghiệp đổ tiền cho đào tạo nội bộ" (The enterprise has spent more money for training), retrieve from http://vnexpress.net/gl/kinh-doanh/2012/04/doanh-nghiep-dotien-cho-dao-tao-noi-bo/, on June 25, 2012 